\title{
Overview on trade secrets in iran law and international documents with approach criminal protection
}

\begin{abstract}
Context and objective: Intellectual property issues arising from the arts and human initiative, but is not present issue with the advent of the human, and intellectual property is also evolved. The aimed of this paper explaining criminal protection of trade secrets in Iran law and international documents.

Research method: The current research is using description-analytic method as well as digital-library sources.

Findings: The findings of the present study indicates that take the experience of industrialized countries and newly industrialized world shows one of the most important factors in the development of proper economic planning and systematically to promote and protect the intellectual property system.

Conclusion: The trade secrets on the one hand is consistent with competition law and on the other hand is one of the examples of intellectual property rights, and is noteworthy because it contains valuable trade secrets and confidential commercial information that may lead to success of a businessman than other competitors. However, the specific nature of trade secrets that makes it unlike other aspects of intellectual property rights protection is not so strong and effective.
\end{abstract}

Keywords: intellectual property, trade secrets, criminal protection, iran law, international documents
Volume 6 Issue 6 - 2018

\author{
Jamal Beigi \\ Assistant Professor of Criminal Law and Criminology, Islamic \\ Azad University, Iran \\ Correspondence: Jamal Beigi, Ph.D in Criminal Law \\ \& Criminology, Assistant Professor of Criminal Law and \\ Criminology, Islamic Azad University, Iran, \\ Email jamalbaigi@iau-maragheh.ac.ir
}

Received: April 23, 2018| Published: November 27, 2018

\section{Introduction}

Intellectual property rights are absolute and exclusive right of exploitation to one of their intellectual creations in the field of industrial, scientific, literary and artistic material and spiritual values. The two branches of literary and artistic property rights, intellectual property rights and industrial and commercial property rights are classified. Industrial and commercial property rights in the field of intellectual property rights assumes that it is the dominant commercial and industrial and information that don't disclose trade secrets or industrial property rights is one of the most important examples in various international instruments, including TRIPS. ${ }^{1}$ A trade secret is any formula, pattern, device information collected is used in trade and the significant economic value is almost independent and to gain an advantage among competitors who are not aware of it and it is not exploited. One of the most famous trade secret is making formula for Coca-Cola. ${ }^{2}$ The company agreed in 1920 with the support of trade secrets; drink recipes from the achieving the company to formula in 1892 was continuously maintained as a secret and this situation is continuing to this day. Aims of the rights of trade secrets is to protect owner's secret against Intellectual property rights are absolute and exclusive right of exploitation to one of their intellectual creations in the field of industrial, scientific, literary and artistic material and spiritual values. The two branches of literary and artistic property rights, intellectual property rights and industrial and commercial property rights are classified ${ }^{3}$ Industrial and commercial property rights in the field of intellectual property rights assumes that it is the dominant commercial and industrial and information that don't disclose trade secrets or industrial property rights is one of the most important examples in various international instruments, including
TRIPS. ${ }^{4}$ A trade secret is any formula, pattern, device information collected is used in trade and the significant economic value is almost independent and to gain an advantage among competitors who are not aware of it and it is not exploited. One of the most famous trade secret is making formula for Coca-Cola. The company agreed in 1920 with the support of trade secrets; drink recipes from the achieving the company to formula in 1892 was continuously maintained as a secret and this situation is continuing to this day. ${ }^{5}$ Aims of the rights of trade secrets is to protect owner's secret against possess or illegal use. Trade secrets to support the development of new ideas is essential importance that, of course, easy access, ease of abuses and full benefits from it, among other features that this type of intellectual property is more susceptible to misuse spiritual and material placed so it requires effective suppuration. Ensure effective implementation of the rights of trade secrets and avoid infringing on the rights they are entitled to support. ${ }^{6}$ Rights in order to guarantee of the various tactics and strategies is called performance guarantee. This study intends to protect the rights of the criminal trade secrets to examine therefore; this study is organized in the following four issues are taken into account. $^{?}$

\section{Examples of trade secrets}

Massive trade secrets and its exploring especially by information secretary, it is difficult. However, examples of trade secrets can be divided into scientific and technical information, business information (business); financial information, corporate data, process, ideas and computer information. ${ }^{8}$

\section{Scientific and technical information}

"Formulas" and "instructions" that are way and guide of the 
production are the most important examples of trade secrets. Formulas of chemical, cosmetic and food and the sum of the terms can be placed in the field of trade secrets. For example, the instruction that the chain restaurant KFC, for fried chicken is its own to the mix composed of eleven species of plants and spices and decades of careful care and safe in the company but, now considered a trade secret. ${ }^{9}$ In 2001 it was reported after the instruction has been used by some individuals, company litigious proceedings, but the evidence was clear that these guidelines do not contain eleven and information about it still remains a mystery. Other examples of trade secrets, "machinery and tool material" which are used during production and competitors are not aware of the existence or operation. ${ }^{10}$ "Numerical calculation methods" that are used in scientific research, together with other circumstances, are a trade secret. "The results of the data analysis" are considered as instances of trade secrets. Trade secret may be a mechanical "plan" for the construction of industrial machinery or plan to provide practical application of new energy in industry. "Model" that companies producing cars, before they offer their products to market, they are considered a trade secret. Early models also offer pre-made model in the opinion of the court has been approved as trade secret." "Templates" are also examples of trade secrets. In some cases, "the" geometry in court opinions has been considered a trade secret, such as automobile airbag protection. "Architectural plans", as well as those entitled trade secret, are protected by law. "Process" in the production of goods and "techniques", which applied to the other samples, is considered trade secrets. "Style "of goods quality control during production or after it is considered trade secret. The information contained in "testing and research," result is the other trade secrets that have been endorsed in several decisions. Sometimes research results or experiences, is full considered and become "knowhow" itself. ${ }^{12}$ Although a clear example of know-how, confidential information, usually it can be registered as an invention, but in the majority of all the information about the invention, the patent does not disclose, but the details of construction and the practical application of the invention, remains solely as technical knowledge belonged to the inventor that is considered a model of trade secrets. It must be remembered that its scope is limited to technical areas and any knowledge on how to do business or skill in a particular area in order to optimize it to work is considered as technical knowledge. ${ }^{13}$

\section{Business information}

The most important examples of trade secrets, is "business plan", and its purpose, plans and strategies of the founder, manager or business owner to organize their activities to achieve business success and business opportunities and benefits anticipated. The holder can prove that significant costs in terms of money and time to do research and expertise necessary to assess the economic cost incurred, demand legal protection for the rights of trade secrets. Business plans should benefit of an innovative and unique features. ${ }^{14}$ Business plans for the transfer of business activities to countries with cheap labor and raw materials are necessary and large firms generally known, but estimates show business plan for example, a country that had not taken into consideration for the transfer of business activities is convenient, confidential information on it is a trade secret. "Marketing plans" for the details of the measures to be taken to develop the market of products or services are examples of trade secrets. The "Promotional plans" before waking up to the public to be sure, are a trade secret. "Ways of doing business" is considered another example of business secrets. Details of "Development of business contracts are of these contracts. ${ }^{15}$ sometimes, in addition to the provisions of the contract, the contracting entity is deemed to be of business secrets, particularly identity of procurement of raw materials are usually hidden from competitors."New business opportunities" are also examples of trade secrets. "Timetable for delivery of products", "lack of products or store it too" "Research and market forecasts" are trade secrets as well. ${ }^{16}$

\section{Financial information}

Financial information is including trade secrets. Personal financial information to competitors, business partners and the people, who interact with them in a way that economic, passion is important, based on this information; these individuals can manage their business operations. Or if the partners are aware of the financial bad situation, its business dealings with him will be limited. Hence, individuals and entities are determined to maintain the confidentiality of your finances. However, information is leaked out. Reports of "corporate earnings," reached of different ways, the "gross" and "net" in term of valuable competitive and are examples of trade secrets. "Sales information" goods (daily, monthly, yearly), is a commercial vendor. Information on estimated selling products that may be put at the disposal of investors has this situation. ${ }^{17}$ Information about the "cost" is trade secret. "Budget information" is examples of financial secrets. "Financial balance", "bank obligations and liabilities of the "View of creditors' "The share of shareholders' investment and other financial information included in the scope of trade secrets.

\section{Organizational information}

Confidential information relating to the businesses agent organization considered as trade secrets. Information such as "opening or closing factories", "buy new companies," "integration with other companies", "the number and identity of key staff" and "major shareholder profile" because of the competition, with all the circumstances, may be the best trade secrets. ${ }^{18}$

\section{Process}

Process, thus collecting data in the different fields with the circumstances referred to them as examples of trade secrets. Gathering information that may be available to the public and they are known, courts are faced with the challenge that you can value secret processes as trade secret? Criteria which courts have considered if it is a measure that usually requires data collection cost, time and activity is significant, as the business process can be supported. In the process, "Customers" and "database" are more important. Customers of competitors it is important for businesses to attract more customers can exercise their market power to raise and attract more interest. The main goal may be to buy a small company to achieve its customer list. Hence, the emphasis was always on the economic value and if company's bankruptcy, customer lists as one of the company's assets by the bailiff's auction. ${ }^{19}$ Customers list in addition to the name, address and telephone number may have other information such as interests and priorities of the purchase or the purchase at a certain time period. The database is a collection of electronic data stored on it, and remarkably, retrieval and processing as well, adapted to the specific conditions of the object protected by trade secret law.

\section{Ideas}

Trade secret law plays the most important role in supporting ideas. Protection of ideas that have commercial value can be the starting point for the activities of a person or company is under formation. Ideas for new products or provide certain services or even the idea of designing a Website may be considered a trade secret. 


\section{Computer information}

"Software", "plan" and "computer code" as examples of trade secrets always have considered by courts. Software and applications companies to design their own internal activities or upgraded versions of the programs that are available to the public seem to be a secret, known as trade secrets. "Alpha" is the initial software design has not yet reached the stage of commercialization are considered trade secrets. ${ }^{20}$ Similar application programs on the market, does not prevent trade secret law of legal protections, provided that the holder can design your application to prove economically worthwhile.

\section{The history of trade secrets protection}

Trade secret protection history goes back to the common law and in between all the major industrialized countries are the world's leading countries in America and England and many countries in the preparation of laws and the laws of this country inspired imitation of them despite these differences, an international principle accepted by all countries and that the value of trade secrets, and as soon as it is based on the secrecy of its disclosure, loses its value, so the story revolves around the key support countries. However, trade secret protection in practical way back to 1951 in England, the United States in 1868. Common law rights in the field with the main objective of establishing research and protect ethical commercial standards formed. Rewritten and civil liability law in 1939, was conducted by the American Institute of Law, the first formal attempt to recognize the rights of trade secrets in the United States, so that it is still considered as a reference to judge the vote. The authors of the second rewrite civil liability, deliberately refused to engage in secret rights, perhaps because the inference Institute of competition law, including trade secrets was varied building..$^{21}$ At the state level regulates rules for trade secrets to 1979 was slow, but in that year the Bar Association of America, the Uniform Trade Secrets Act, as the samples law were passed. In addition, the third edition of the unfair relations in 1995, published by the American Institute of Law, contains provisions concerning trade secrets is relatively advanced. In 1966, the Economic Espionage Act passed the first federal legislation to be considered in the context of trade secrets. Solely to protect the confidentiality of criminal sanctions is the clincher. The way for the lawsuits, but from civil liability for loss or contractual eyes open is not create an obstacle in the path. The rights of Iran the less well-known trade secrets as far as studies show that the oldest document that refers to the trade secrets 05.09.1951 approved the Statute of the National Iranian Oil Company, paragraph 9 of Article 4 of the National Iranian Oil Company in gaining secrets and confidential information through purchases or other legal means allowed. ${ }^{22}$

\section{Methods of protect trade secrets}

Although the protection of trade secrets, the secrets plays the central role the following methods have been mentioned as a means of protecting trade secrets.

\section{Physical and logical security}

Archive properly and keep out of reach of information and appropriate protection systems can be embedded in the privacy of its owner or holder of the company and to help the company's secrets.

\section{Nondisclosure contract}

Under the nondisclosure agreement, maintain secret information and avoid disclose them. So if a person violates his contract, the contract can be more revealing secrets warned him of breach of contract and also damage the court's demand. However, in the case of employees who participate in any way obliged to keep their employer's trade secrets, the conclusion of such an agreement is not always necessary. Different types of trade secrets to conclude this agreement can be supported by the contract. Use non-disclosure agreement, at the corporate level, especially Internet companies and the computer used. However, the objective of the contract is not known but to the conclusion of the contract creates a confidential relationship between the parties, and any other person who owns trade secrets and one of them is bound to non-disclosure of secrets. So the only people, who have a secret relationship, are legally required to keep the information secret. In terms of the contract according to the principle of freedom of contract is recognized that the nature and the conclusion of contracts and how they are governed. This type of contract can be oral or implied signed or deduced from the behavior of the parties, but traders and businesses are less willing to enter into this Agreement and are often verbal, the contract will be concluded in writing, as proof of an oral agreement, especially in the case of the need to prove the confidentiality of information, it is difficult. The best method for maintaining the confidentiality and non-disclosure contracts advantage of this is litigious dispute in court if it comes to the issue of disclosure of secrets, secrets owner should read both the confidentiality of information and access to this information through illegitimate and by resorting to illegal means to prove, but if there is such a contract, demand, without proof of the fact that mere nondisclosure contract, represents a violation of the confidentiality of information and it is also an illegitimate way. ${ }^{23}$

\section{The Criminal Protection of Trade Secrets}

Since the criminal protections caused imposition intentionally, deliberately and systematically suffering, pain and deprivation of natural rights, and this in turn with reason and conscience are not acceptable unlike property, life, dignity and freedom of human beings and their actions even in the mildest form of the inalienable rights of all or a conflict is therefore justifiable actions. It punishes itself is morally bad, evil and discouraged, theoretical and practical justification and without any religious or common sense did not support it. Owners of trade secrets in addition to being involved in the interests of public use of their works, others are entitled to protection against unauthorized use; thus, the legal protection of such property is not only important, but more important reason. Creators of intellectual property violations and lack of effective legal protection for delinquent behavior, threatening economic security and public order; for protection under penal provisions for the owners of these rights will be considered, incentive for creativity and innovation in new creations. In addition, the ease of access, ease of abuses and massive profits derived from such properties and this type of material and intellectual property is more susceptible to misuse put; therefore, it is necessary for effective legal protection. ${ }^{24}$ Crimes against trade secrets in the general category belonging to crimes against property and this does not imply that these crimes do not distort the internal or external security on the contrary, in many cases it is possible and the secrets crimes in the economic disruption in the system can cause directly belong to the category of crimes against the security and the material it is not very important. Despite possible crimes against trade secrets belonging to both categories of crimes, except in rare cases can be classified under crimes against property. Criminal breach of the confidentiality of trade secrets and lack of support that could hurt the country in many different ways; on the one hand will prevent the 
flourishing of local thinkers and creative genius; because if people can easily obtain their achievements, incentives for investment and time to produce not think on the other hand impede investment and transfer of knowledge and technology to the country; for developed countries, in the absence of adequate protection of trade secrets, will not appetite for technology transfer to the country.

Confidentiality breach of trade secrets in the criminal law is expected to be limited. Before the revolution, paragraph (e) of Article 249 of the Penal Code amended in 1931 to criminalize violations of trade secrets had been considered. This article does not cover all aspects of trade secrets and mysteries of the invention apply only to violations if the disclosure or use of the offender was sentenced to the punishment prescribed by law. The other rules that a violation of the confidentiality of trade secrets related can be "Criminal Law Act 1973 of leaking confidential documents and secret government" pointed further, the law relating to trade secrets in violation of state secrets. After revolution the scattered rules are vague and incomplete it for violating the confidentiality of trade secrets in real space pointed which can hardly be used to punish violators; for each of the many uncertainties and constraints encountered. In other words, the more crime family secrets, government, security, professional, career, etc. was relating to trade secrets. Some of these rules may be suspended by Article 648 of the Penal Code is noted that the violation of professional secrets. Article 46 of the Securities Market Law 2005, the Islamic Republic of Iran to the people with the Securities Market Act relating to the securities received a tip-off and a fine predicted. In addition to these rules, 501 and 503 of the Penal Code, adopted in 1996 as part of sanctions is to achieve and public disclosure of secrets, Article 77, "the Ministry of Information," the ministry's employees is required to protect the confidentiality of the series, Article 12 of the law of "direct tax" law passed in 1938 on official experts are related to a violation of trade secrets. The totality of these rules in a way relates to their trade secrets. Articles 544 and 604 of the Penal Code Act of 1996 suspended the infringement procedure concerning the protection of government documents and public officials in the state require sanctions in this regard determine which indirectly may not disclose information within the strict sense of the word is used. Prior to the adoption of e-commerce law, certain provisions to punish violators of privacy rights of any trade secrets in the cyberspace; therefore, some judges to fill the legal vacuum, violation of trade secrets to achieving the three elements of the crime of malversation as punishable knew; for example, Branch 31 of Tehran appeals court petition No. 1269, unlike clause contained in a contract employee of the Company, the information in the computer the unauthorized copying and adding other information in the exhibition was a diskette, according to Article 674 of the Penal Code by the sanctions have been sentenced for the crime of malversation. With the approval of the "Law on Electronic Commerce" in 2003, the gap has been resolved and trade secrets, breach of confidentiality in the context of electronic transactions were criminalized. This applies only to the educated and illicit trade secrets, breach of confidentiality of trade secrets and other examples of the use of its trade secrets, the elimination of trade secrets, etc. not. Trade secret protection in cyberspace, innovation, e-commerce legislation is enacted in 2003; the law of trade secrets, breach of privacy in the digital space, or in the context of electronic transactions is criminalized..$^{25}$ Legal elements of the crime ink and in Article 65 and 75 of the law of electronic commerce are predicted by means of the 64 states examined the material element Article 65 is also referred to as trade secrets, while the penalty for this offense is prescribed in Article 75. In terms of the physical behavior of the material element of the offense in the form of positive action; the illegal trade secrets and economic education for themselves or disclosure to third parties in the electronic environment. Education as the means available obtains and discloses the secrets. Legislative conditions for the realization of this crime have decreed that must be met by the judge. First, education or disclosure of trade secrets in the context of electronic transactions is committed, i.e. if the crime in real space will be subject to this law. Second, the offense must be of the trade secrets and other secrets of family, honor, etc., are not subject to this law. Trade secret is information that has commercial value. Economic secrets about the economic issues must be met by the judge. The mental element of the crime of intentional crimes, and committed to the free will to do it and education or disclosed in a drunken sleep or anesthesia or coercion and compulsion is not the cause for the crime. The perpetrator must have knowledge in the first place, the school head is illegal; secondly, what makes studying or disclosure, is secrets. Physical behaviors were very limited examples provided in this Act it is best to act as a legislator and terms and word add other things to it; for example, if someone out the trade secrets or alter or distort, will not be subject to this law. To apply as a criminal theft of trade secrets and the secrets of the owner of the property shall be appropriated kidnapped. Considerations suggest that the concept evolved over time property and intangible property is developed. In other words, the efforts that have been introduced to the concept of private property rights in the criminal law must be developed. No. 308 dated 20.09.1940 the voting rights of the 5 branches of the Supreme Court considered the possible theft of electricity is thought to facilitate the theft of trade secrets as well. In any case the law of attraction is one of the robberies, but does not explicitly in the common law rights and the common law of appropriation may be used as a general concept of abduction. ${ }^{26}$ To analyze the elements of theft of trade secrets should be noted that as the embodiment of foreign trade secrets can be divided into two major categories. Trade secrets within the first hardware devices and machines are unique they steal and steal the secret of secrets, secrets are also considered to be second class which have the capability to reproduce or disclose and any action in this case leads to the loss of economic value or, in rare cases it may be worthless. Among other crimes related to trade secrets and economic espionage can be cited. Economic espionage is somehow related to security and national interests and the punishment prescribed for the offense in most legal systems heavier than stealing trade secrets.

\section{Conclusion}

The protection of intellectual property rights for the world's top technology innovators, inventor of critical and importers for this technology is undeniable problem in order to facilitate international trade and international development is not only a positive step in the interests of taxpayers and the transfer of technology transfer recipients it can be a deeper insight and foresight to move more in the direction of universal human being considered. The preservation of trade secrets, unlike all discussions and actions has been taken to limit the principle. Certainly the world of business will not flourish without Privacy growth. Our current needs in the context of commercial transactions and consequently in the law of trade secrets, the rate predicted by the rules of competition law is to explain the limits of this contract; no doubt the subject matter of contract, depending on the complexity of the issue of commercial competition, not very helpful and although the owner of the trade secret protection plays a major role Secrets however, all countries should recognize the importance of trade secrets and take the necessary measures to prevent the disclosure 
of these secrets do. In their criminal legislators feel compelled to intervene in support of trade secrets known to prevent crimes or punish the perpetrators of crimes against trade secrets.

\section{Acknowledgments}

None

\section{Conflicts of interest}

The author declares that there is no conflicts of interest.

\section{References}

1. Asghari, Aq Mashhadi, Fakhr Al-din. Introduction to Intellectual Property Rights. Mazandaran University Press. 2012.

2. Alsan M. Trade secret rights in the age of information technology. Legal journal of Justice. 2005;51.

3. Crimes against trade secret Law Quarterly. 2008;38(4).

4. Alsnhory, Alosyt. Third Edition, charter Aljly Alhqvqyh, Beirut, Lebanon. 1998;2.

5. Imami, Hassan. Civil Rights, Tehran, Tehran University Press, 1956; (1).

6. Ansari A. Examining leading Muslim rule and the authority of the Association Bulletin. 2006;67.

7. Bashiri A, M Porrahim. Trade secret electronic application, printing, publishing immortal. 2011.

8. Jafari, Amin. Professional secrets and Commercial Criminal Law. Jurisprudence and Law Journal. 2007;14.

9. Haji Azizi, Bijan. Assignment of rights and comparative terminology, technology transfer. MS Thesis privacy, martyr Beheshti University. 1992.

10. Hekmatnia Mahmoud. The basics of intellectual property. Press Institute of Culture and Islamic Thought. 2007.

11. Dablfon, Zoyeh Linan. E-commerce law, translated by S. Zarkolam
Press Shahrdansh. 2011. Rahbari E. Trade secret rights, publishing side, since the first. 2009.

12. The restrictive agreements on the protection of trade secrets law study in America, England, France, Iran. Journal of Legal Studies. 2009;(50).

13. Rezaei Far M. Legal protection of a trade secret.

14. Shahidi M. Forming contracts and obligations of the lawyer. 1998

15. Bariklo AR. contracts no trade, no till.

16. Saberi, Rouholah. License agreements, knowledge Nshrshhr. 2008.

17. Sadeghi. A comparative study of the competent authority designated to handle lawsuits violation of trade secrets in the digital space. Journal of Business Research. 2010;55.

18. Sadeghi vitality, Amir. Protection of authors' rights in computer software, publications. The Secretariat of the Supreme Council of Information. 1997.

19. Tabatabai Yazdi, Mohammad K. Roh Alosqa Altlyqat Nevertheless, Institute for Family Publishing House. Volume 2.

20. Abbasi, Solmaz, Mahdipour Qazvini, et al. Trade secrets and how to support them.

21. Alavi SMH. Protection of intellectual property rights in criminal law in the light of international instruments, MS Thesis, Faculty of Law and University of Shahid Beheshti. 2005.

22. Mir-Hosseini, Seyed Hossein. Introduction to Intellectual Property Rights, Second Edition. Tehran, emission rate. 2006.

23. Najafi Tavana, Ali Amini M. Protection of trade secrets criminal law and the federal laws of America. Islamic Law Journal. 2011;8(29).

24. Albert Sylvia N. Intellectual Property Crimes. American Criminal Law Review. 2005;42(2).

25. Elias, Stephan. "Trade Secrets Law, an Overview". 1998.

26. Mccarthy JM. Intellectual property. 2003. 